\title{
Effects of Participation of Micro and Small Enterprises in Microfinance on Their Performance in Kenya
}

\author{
Forah M. Obebo $^{1}$, Nelson H. W. Wawire ${ }^{1}$ \& Joseph M. Muniu ${ }^{1}$ \\ ${ }^{1}$ Department of Applied Economics, School of Economics, Kenyatta University, Nairobi, Kenya \\ Correspondence: Forah M. Obebo, Department of Applied Economics, School of Economics, Kenyatta \\ University, P.O Box 43844 -00100, Nairobi, Kenya. E-mail: forahobebo@gmail.com or obebo.forah@ku.ac.ke
}

Received: May 15, 2018

doi:10.5539/ijef.v10n7p78
Accepted: June 1, 2018

Online Published: June 5, 2018

\begin{abstract}
The development of the microfinance sub-sector in Kenya is seen as a favourable catalyst for increasing performance of Micro and Small Enterprises (MSEs). Despite the development, MSEs continue to suffer from high levels of financial exclusion and shortage of operating funds. This scenarios raise policy questions on whether participation in microfinance has effects on performance of MSEs. While past studies on this relationship have demonstrated that the effects are mixed, an understanding of the effects on participation of microfinance on different segments on MSEs - especially the youth and women owned businesses and age of businesses, is necessary in designing relevant policy changes in the MSE subsector. To address this, the study used the 2016 FinAccess Dataset and estimated these effects using the propensity score matching technique. This model was considered suitable since it accounted for potential endogeneity biases associated with self-selection into participation, unobserved entrepreneurial abilities and risk taking behaviour of MSEs. Apart from showing that participation in microfinance has positive effects on performance of MSEs, the study has demonstrated that there is presence of constraints limiting the impact of microfinance especially in firms owned by the youth and women. As such, there is need for policy and product designs to address these hindrances even as participation in microfinance is encouraged. Based on the results, it is recommended that government and microfinance providers should design policies and products that increase firm participation in microfinance. This may be through scaling up financial literacy programmes and encouraging acquisition of permits. Finally, policy should address obstacles that hinder the youth and women owned MSEs from benefiting from microfinance.
\end{abstract}

Keywords: micro and small enterprises, microfinance, propensity score matching, probit, endogeneity

\section{Introduction}

The emergence of microfinance provides an avenue for provision of various services to the MSEs such as microcredit, microsavings, microinsurance, financial literacy services, training and business networking. These services are often designed in relatively small transactions and are accessible and affordable to the MSEs (Copestake et al., 2001; Tedeschi, 2008). Therefore, participation in microfinance can help MSEs overcome challenges such as inadequate capital, lack of access to affordable credit, lack of collateral and inadequate managerial and technical skills (Republic of Kenya, 2013a).

In Kenya, MSEs are well recognised in the Kenya Vision 2030 as drivers of economic growth and employment (Republic of Kenya, 2007). On its contribution to economic growth, the sector accounted for 33.8 percent of the Gross Domestic Product (GDP) in the year 2015 (Republic of Kenya, 2016). This share was an increase from 18.4 percent in 1999 when the country had its first MSE baseline survey (Republic of Kenya, 1999). Regarding employment, the sector employed at least 14.9 million people in 2015 accounting for at least 90 percent of the total employment in Kenya. Overall, micro enterprises comprised 81 per cent of the total employment while the remainder was for small and medium enterprises (Republic of Kenya, 2016).

The MSEs in Kenya are characterised by the licensing status, number of employees, registration status and economic activity. Overall, there were 7.4 million business establishments in Kenya in the year 2015. Of all these establishments, 1.5 million businesses were licenced while 5.9 million were not. On classification by number of employees, 81 percent of the total businesses were microenterprises (1-9 employees) while 19 percent were either small (10-49 employees) or medium enterprises (50-99 employees). On registration status, 73 percent of all businesses were under sole proprietorship while the rest included, partnerships, groups, 
cooperatives, private companies and public companies. (Republic of Kenya, 2016). Considering the levels of business income, the sector reported an average normalised monthly turnover (in the period 2011-2016) of Kshs 635 billion of which Kshs 569 billion were due to licenced businesses while the difference accrued to the unlicensed businesses (Republic of Kenya, 2016).

Given the contribution of businesses in supporting the economy, the Government of Kenya has initiated a number of policies and programmes including; Sessional Paper No 2 of 1992 on Small Enterprises and Jua Kali Development, Sessional Paper No 2 of 2005 on Development of Micro and Small Enterprises, Micro and Small Enterprises Act of 2012 and creation of government administered funds. The overall thrust of these policies was to overcome challenges faced by MSEs including; limited access to financial services, high transaction costs, inadequate business skills, lack of business networking and limited access to appropriate technology (Republic of Kenya, 1986; 1992; 2005; 2012; 2013b).

A key development from these initiatives was the emergence of microfinance - a subsector viewed as a catalyst for enhancing MSE performance in developing countries (Demirguc-Kunt \& Klapper, 2012; Rooyen et al., 2012). Through some of these policy efforts, the microfinance sub-sector has recorded considerable developments including; increase in gross lending by leading microfinance banks from Kshs 707 million in 1999 to Kshs 254 billion in 2015; increase in the number of licensed microfinance banks from one in 2009 to 13 in 2016 and; increase in the usage of informal microfinance from 32 percent in 2006 to 41 percent in 2016 (Republic of Kenya, 2012; CBK, 2015; CBK, KNBS \& FSD-Kenya, 2016).

Typically, the emergence of microfinance is potentially a suitable alternative in addressing financial exclusions of MSEs. This is because microfinance attributes can address financial access challenges such as stringent collateral requirements, adverse selection and moral hazard and lack of business support services (Armendariz \& Morduch, 2005). Therefore, MSEs who would ordinarily be excluded from accessing finance from mainstream financial providers should access these services through microfinance providers. Despite the development of the microfinance subsector in Kenya, MSEs continue to face challenges of access to affordable finance thus affecting their performance.

In the period 2011-2016, at least 2.2 million businesses closed with the average age of closure being 3.8 years. The main reasons of closure were financial exclusion and shortage of operating funds, among other challenges (Republic of Kenya, 2012; Republic of Kenya, 2016). Of these businesses that closed, about 46 percent of them closed within the first year of operation. In addition, businesses that were under two years of age were the most vulnerable to closures as they accounted for 61.3 per cent of the total closures (Republic of Kenya, 2016). Moreover, the Medium Term Framework II (2013-2017) of the Kenya Vision 2030 plan indicated that high levels of exclusion from financial services, low utilization of financial services and inadequate access to finance are some challenges that continue to affect performance of MSEs (Republic of Kenya, 2012). Therefore, an understanding of how microfinance affects MSE performance is necessary for designing policies towards addressing some of these challenges facing MSEs. This particularly important for the government in terms policy design of using microfinance to support youth and women -owned businesses. Also, this information may help the providers to design products and incentives that would promote uptake of microfinance products by MSEs.

The nexus between development of microfinance and financial exclusion of MSEs raises policy questions on whether participation in microfinance has effects on MSE performance. Studies on this relationship, have demonstrated that the effects are mixed (Copestake et al., 2001; Copestake et al., 2005; Tedeschi, 2008; Augsburg et al., 2015; Banerjee et al., 2015; Tarozzi et al., 2015; Crepon et al., 2015). While these studies are useful for policy design, an understanding of the effects of participation of MSEs in microfinance on different segments - especially the youth and women owned businesses and age of businesses, is necessary in designing relevant policy changes in the subsector. Also, the study will account for the significant microfinance developments that have taken place in Kenya in the last decade. Therefore, the objective of this study is to determine the effects of participation of MSEs in microfinance on their performance in Kenya.

\section{Literature Review}

The theory of a firm is one of the neo-classical theories that can be used to describe the behaviour of a firm in relation to profit, production and cost. The earliest foundations of this theory date back to the works of Smith (1776), Knight (1921) and Coase (1937) who stressed that firms sought to achieve the objectives of profit maximisation, production maximization and cost minimization. Based on this foundations, the effects of participation of MSEs in microfinance on their performance is based on the theory that a firm seeks to maximise its profit subject to a production constraint. A firm with multiple inputs and multiple outputs seeks to maximize its profits with an optimal indirect profit function which can be written as 


$$
\pi^{*}(p, w)=p f\left(x^{*}(p, w)\right)-w x^{*}(p, w)
$$

Where $\pi(p, w)$ is profit of the firm, $p$ is output price, $w$ is input price, $y$ is vector of outputs and $x$ is a vector of inputs.

To characterise how microfinance influences firm profit, the reduced-form optimal input demands and output supply functions can be modified to incorporate participation in microfinance as one of the choice variables. An extended indirect profit function thus becomes

$$
\pi\left(p, w, m ; F^{h}\right)=p f\left(x^{*}(p, w, m)\right)-w x^{*}(p, w, m)
$$

Where $m$ represents participation in microfinance and $F^{h}$ is a set of firm, firm-owner and institutional characteristics.

Equation 2 implies that participation in microfinance is one of the choice variables that can affect the profitability level of MSEs. It is assumed that MSEs who are undercapitalized or excluded from the formal financial markets can borrow from a microfinance to expand their capital inputs and in turn increase their profit through higher output. This may be through purchase of productive assets such as machines to increase production, investing in new technology and increasing human capital (Zeller, 1999 and Arun et al., 2009). As production expands, the production constraint is relaxed thus increasing the overall profitability of the firm.

Since participation in microfinance is a discrete variable, the use of first order conditions cannot yield an interior solution to an optimal microfinance level (Key et al., 2000). The optimal choice for participation in microfinance, can only be derived by the firm`s comparison of profits in the two regimes. Firms will choose to participate or not by comparing the level of profits due to participation with the level of profits due to non-participation and will choose to participate if the profits due to participation $\left(\pi_{p}\right)$ are greater than the profits due to non-participation $\left(\pi_{N}\right)$ such that

$$
\pi_{p}\left(p, w ; F^{h} / m=1\right)>\pi_{N}\left(p, w, F^{h} / m=0\right)
$$

It is on the basis of this comparison that the effects of MSE participation in microfinance on their performance is analysed.

On the empirical front, studies by Copestake et al., 2001; Copestake et al., 2005; Tedeschi, 2008; Gubert \& Roubaud, 2011; Augsburg et al., 2015; Banerjee et al., 2015; Tarozzi et al., 2015; Crepon et al., 2015) generated mixed results. While these results may be useful in addressing policy gaps around financial exclusion of MSEs, the studies did not capture the microfinance effects on certain key segments of MSEs such as age of businesses and performance of both youth and women owned enterprises.

\section{Methods}

\subsection{Theoretical Framework}

To estimate the effects of participation of MSEs in microfinance on their performance, a treatment effects model was considered. This was due to the need to address potential endogeneity biases associated with unobserved variables. These biases may be associated with entrepreneurial abilities and risk taking behaviour of the firm (Tedeschi, 2008). To account for this biases, the Propensity Score Matching (PSM) by Rosenbaum and Rubin (1983), was used.

PSM is a non-parametric technique which does not depend on the functional form or distributional assumptions of a model (Rosenbaum \& Rubin, 1983). The method is used to match observations of participants and non-participants according to the predicted propensity scores of the treatment variable. The matching procedure creates the conditions of a randomized experiment in order to estimate a causal effect of the variables. The coefficients of the matching process enjoy unbiased and consistent estimators (Awotide et al., 2015). The first step of the model was to estimate the propensity score of participation in microfinance. The propensity score is the conditional probability of assignment to a particular treatment given a vector of observed covariates (Rosenbaum \& Rubin, 1983). Since this is a non-randomised experiment, the propensity scores are almost unknown but may be estimated with observed data using one of the common approaches such as probit regression.

To generate the probit model, let $\pi_{p}$ be the profit of a firm that is due to participation and $\pi_{N}$ be the profit of a firm that is due to non-participation. For firms to choose to participate or not, it must that they have an unobservable critical level of profits that would make them take the decision. The critical level of profits may be given as

$$
\pi^{*}=\pi_{p}-\pi_{N}
$$


Since this decision stage is not observable, it can be represented by a latent variable $\left(F_{i}\right)$ which is defined as

$$
F_{i}=1 \text { If } \pi^{*}>0 \text { and } F_{i}=0 \text { if } \pi^{*} \leq 0
$$

Equation 5 implies that firms will participate in microfinance $\left(F_{i}=1\right)$, if the critical profit is greater than zero, otherwise, they will not participate $\left(F_{i}=0\right)$.

The probit model to be used can be specified as

$$
\operatorname{Pr}\left(F_{i}=1\right)=\phi\left(T^{\prime} \delta\right)
$$

Where $F_{i}=1$ is the treatment, $T^{\prime}$ is an observed vector of the firm, firm-owner and institutional covariates that affect participation in microfinance, $\delta$ is a vector of unknown parameters, $\eta$ is a random error term and $\phi$ is the cumulative distribution function of a standard normal random variable, that is, a normally distributed random variable with mean of zero and a constant variance for the error term (Verbeek, 2012). Using the probit model in Equation 6, the propensity score was estimated as

$$
p(T)=\operatorname{Pr}\left(F_{i}=1 / T\right)
$$

Where $p(T)$ is the propensity score and $\operatorname{Pr}\left(F_{i}=1 / T\right)$ is conditional probability of assignment to participation in microfinance (treatment) given a vector of observed determinants of MSE participation in microfinance ( $T$ ).

To ensure that the propensity scores can be used for matching, two assumptions must be satisfied. First, the model assumes the unconfoundness or conditional independence assumption which may be stated as

$$
\pi_{P}, \pi_{N} \perp F / T
$$

Where $\pi_{p}, \pi_{N}, T$ are as before, $F$ is the treatment (participation) and $\perp$ means independence. Equation 8 implies that firms have the same distribution for their outcomes, regardless of participation or non-participation status. Given this assumption, it becomes possible to construct a suitable simulation for estimating the participation effects (Verbeek, 2012).

Second, the common support or overlap assumption assumes that the propensity scores $\left(\operatorname{Pr}\left(F_{i}=1 / T\right)\right.$ are bounded between zero and one such that

$$
0<\operatorname{Pr}\left(F_{i}=1 / T\right)<1
$$

The second assumption assumes that all the treated units have a counterpart in the control population. If any of the propensity scores are equal to zero or one, then these will be outside the region of common support and will not be successfully matched. If these two assumptions are satisfied, propensity scores can be successfully matched using a suitable matching algorithm. In the study, nearest neighbour matching (NNM) algorithm was considered suitable since in the case of large samples, it can minimise bias during matching and also produce good quality matches (Smith \& Todd, 2005). In matching, the propensity scores were compared between the treated observations (participants) and control observations (non-participants) such that the differences or Average Treatment Effect on the Treated (ATET) in the outcome variable (firm income) could be attributed to participation in microfinance. The ATET can be defined as

$$
A T E T=E\left(\pi_{p} / F=1\right)-E\left(\pi_{N} / F=1\right)
$$

Where $E\left(\pi_{P} / F=1\right)$ the expected outcome of treated firms conditional on participation and $E\left(\pi_{N} / F=1\right)$ is the expected outcome of the non-treated firms conditional on participation.

\subsection{Empirical Model}

Based on Equation 10, the PSM model estimated the ATET as

$$
A T E T=E\left(Y_{p} / F=1\right)-E\left(Y_{N} / F=1\right)
$$

Where $E\left(Y_{p} / F=1\right)$ is the expected annual firm income of treated firms conditional on participation and $E\left(Y_{N} / F=1\right)$ is the expected annual firm income of non-treated firms conditional on participation. The estimation, $E\left(Y_{N} / F=1\right)$ is based on a simulation of what the firm income would have been for the participating firms had they not participated.

\subsection{Data and Variables}

To achieve the objective of the study, data was collected from the 2016 FinAccess dataset. The data is a cross-sectional survey that was conducted by Central Bank of Kenya, Kenya National Bureau of Statistics and FSD-Kenya in the year 2015. The dataset contained modules whose data included that of firm, firm-owner and finance variables. Table 1 presents the definition and measurement of variables used in the study. 
Table 1. Variables for MSE participation in microfinance and MSE performance

\begin{tabular}{|c|c|}
\hline Variable & Definition and Measurement \\
\hline $\begin{array}{l}\text { MSE participation in } \\
\text { microfinance }\end{array}$ & $\begin{array}{l}\text { If an MSE (firm) borrowed microfinance credit in the past year from a microfinance bank / ROSCA/ } \\
\text { ASCA/ Supplier where, } 1=\text { MSE participates and } 0=\text { Otherwise }\end{array}$ \\
\hline Annual firm Income & The annual gross income earned by an MSE (firm) in the past year in Kshs \\
\hline Number of business units & The number of independent businesses operated within the firm in the past year. \\
\hline Age of firm owner & The age of the firm owner in years \\
\hline Age of firm & The number of years the firm has been in operation \\
\hline Number of employees & The number of employees of the firm in the past year ( casual or permanent ) \\
\hline Education level of firm owner & $\begin{array}{l}\text { The highest education level attained by the firm owner where, } 1=\text { No Education } 2=\text { Primary, } 3= \\
\text { Secondary and } 4=\text { Tertiary }\end{array}$ \\
\hline Gender of firm owner & The gender of firm owner where, $1=$ male and $0=$ female \\
\hline $\begin{array}{l}\text { Financial literacy level of } \\
\text { owner }\end{array}$ & $\begin{array}{l}\text { Whether a firm owner correctly answered a set of simple financial questions where, } 1=\text { Financially } \\
\text { Literate and } 0=\text { Otherwise }\end{array}$ \\
\hline Numeracy level of owner & $\begin{array}{l}\text { Whether the firm owner correctly answered a set of numerical questions where, } 1=\text { Numerate and } 0= \\
\text { Otherwise }\end{array}$ \\
\hline Ownership of radio by owner & Whether the firm owned a functioning radio in the past year where, $1=$ Yes and $0=$ No \\
\hline Location type of the business & $\begin{array}{l}\text { The type of location of the business whether fixed or not fixed in the past year where, } 1=\text { Fixed and } 0= \\
\text { Not Fixed }\end{array}$ \\
\hline Business Permit & Whether a firm possessed a valid business license or permit in the past year where, $1=$ Yes and $0=$ No \\
\hline Formal Registration & $\begin{array}{l}\text { Whether a business was formally registered either as a sole proprietorship, company or partnership in } \\
\text { the past year where, } 1=\text { Yes and } 0=\text { No }\end{array}$ \\
\hline Motorbike & Whether a firm owned an operational motorbike in the past year where, $1=$ Yes and $0=$ No \\
\hline Bicycle & Whether a firm owned an operational bicycle in the past year where, $1=$ Yes and $0=$ No \\
\hline Credit policy (Outward) & Whether a firm ever issued credit to its customers in the past year where, $1=$ Yes and $0=$ No \\
\hline Credit policy (Inward) & Whether a firm ever received credit from its suppliers in the past year where, $1=$ Yes and $0=$ No \\
\hline Bank finance participation & Whether a firm ever borrowed credit from a commercial bank in the past year where, $1=$ Yes and $0=$ No \\
\hline
\end{tabular}

\section{Results and Discussions}

\subsection{Descriptive Statistics}

The descriptive statistics of the variables that were used to analysis are described in Table 2

Table 2. Descriptive statistics

\begin{tabular}{|c|c|c|c|c|}
\hline \multirow[t]{2}{*}{ Variable } & Sample & Participants $(N=471)$ & Non-Participants $(\mathrm{N}=1354)$ & Difference \\
\hline & Mean (SD) & Mean (SD) & Mean (SD) & Mean \\
\hline \multirow[t]{2}{*}{ Annual Firm Income } & 138,495 & 170,466 & 127,326 & $43,140 * * *$ \\
\hline & $(137,669)$ & $(170,134)$ & $(121,491)$ & \\
\hline \multirow[t]{2}{*}{ Number of business units } & 1.09 & 1.142 & 1.074 & $0.759 * *$ \\
\hline & $(0.452)$ & $(0.620)$ & $(0.383)$ & \\
\hline \multirow[t]{2}{*}{ Age of firm owner } & 37.09 & 40.14 & 36.03 & $4.11 * * *$ \\
\hline & $(14.27)$ & $(12.75)$ & $(14.62)$ & \\
\hline \multirow[t]{2}{*}{ Age of firm } & 7.010 & 7.746 & 6.753 & $0.993 * *$ \\
\hline & $(8.015)$ & $(8.005)$ & (8.006) & \\
\hline \multirow[t]{2}{*}{ Number of employees } & 1.576 & 1.909 & 1.460 & $0.449 * * *$ \\
\hline & $(1.639)$ & $(2.323)$ & $(1.300)$ & \\
\hline Education (No education) & 0.991 & 0.0233 & 0.1256 & $-0.1023^{* *}$ \\
\hline Education (Primary) & 0.4603 & 0.4016 & 0.4807 & -0.0791 \\
\hline Education (Secondary) & 0.3246 & 0.4208 & 0.2910 & $0.1298 * *$ \\
\hline Education (Tertiary) & 0.1160 & 0.1543 & 0.1027 & 0.0516 \\
\hline Gender of firm owner & 0.7712 & 0.7949 & 0.7629 & 0.320 \\
\hline Financial literacy level of owner & 0.7570 & 0.9006 & 0.7068 & $0.1938 * * *$ \\
\hline Numeracy level of owner & 0.6984 & 0.7970 & 0.6640 & $0.1330 * *$ \\
\hline Ownership of radio by owner & 0.6196 & 0.7167 & 0.5857 & $0.131^{* *}$ \\
\hline Location type of the business & 0.6935 & 0.7505 & 0.6736 & 0.0769 \\
\hline
\end{tabular}




\begin{tabular}{|c|c|c|c|c|}
\hline Business Permit & 0.2332 & 0.3594 & 0.1891 & $0.1703^{* * *}$ \\
\hline Formal Registration & 0.1034 & 0.1438 & 0.0893 & 0.0545 \\
\hline Motorbike & 0.1429 & 0.1650 & 0.1352 & 0.0298 \\
\hline Bicycle & 0.2129 & 0.2558 & 0.1980 & 0.0578 \\
\hline Credit policy (Outward) & 0.7088 & 0.7378 & 0.6987 & 0.0391 \\
\hline Credit policy (Inward) & 0.3897 & 0.4397 & 0.3722 & 0.0675 \\
\hline Bank finance participation & 0.0626 & 0.1235 & 0.0415 & 0.0820 \\
\hline
\end{tabular}

$\mathrm{N}=$ Number of Observations; S.D = Standard deviation in parenthesis; Asterisks ***, **, * denote levels of statistical significance at $1 \%, 5 \%$ and $10 \%$, respectively. Source: Own Computation from Study Data (2017).

From Table 2, the total sample used for analysis was 1,827 micro and small enterprises (firms). Of the sample firms, about 25 percent participated in microfinance while 75 percent did not. This implies that microfinance credit use is still low among firms. While this level of use is low, microfinance use is higher compared to commercial bank finance whose level of use was 6.26 percent. Therefore, more MSEs were thought to use microfinance services than the formal banking services for their business needs. Overall, the variables of annual firm income, number of business units, age of firm owner, number of employees, education (no education), education (secondary), financial literacy level of owner, numeracy level of owner, ownership of radio by owner and business permit demonstrate that their exist differences between participant and non-participant firms. However, a direct comparison of the differences between these two regimes in order to determine microfinance effects may be misleading since it does take into account the endogeneity and self-selectivity of the choice to participate or not.

\subsection{Effect of Participation of MSEs in Microfinance on Their Performance}

The first step of PSM was to estimate a binary probit model given the MSE`s probability of participating in a microfinance. The probit regression was estimated using the maximum likelihood estimation procedure (MLE) and the output is presented in Table A1 in the appendix. Based on this output, a number of post-estimation diagnostic tests were undertaken to check for validity of the model. A multicollinearity test done using the Variance Inflation Factor (VIF) showed that the model did not suffer the problem as all the VIFs for all variables were less than 10. The results of the Link test, Hosmer-Lemeshow test and Langrage-Multiplier test showed that the model was correctly specified, the data was well fitted and there was absence of heterokedasticity (see Table A2). Overall, the diagnostic tests show that the probit model was suitable for generating propensity scores.

After the propensity scores were obtained, a matching process using the nearest neighbour matching (NNM) algorithm was conducted. In the matching process, the propensity scores were compared between the participant and non-participant firms such that the differences in the annual firm income could be attributed to participation in microfinance. To check for robustness of the matching process, the model was subjected to two tests. First, the results in Figure A1 showed that there was considerable overlap of the propensity scores between the treated and control variables thus matching would be successful. Second, the results of the balancing test in Table A3 show that there were no significant differences of the covariates after matching as all the p-values of the test for differences in the covariates were statistically insignificant. Therefore, the balancing test demonstrates that matching was successful.

To calculate the effect of microfinance participation on MSE performance, the difference in average firm income between the two matched groups was estimated as shown in the next table.

Table 3. PSM results of the effect of MSE participation in microfinance on MSE income

\begin{tabular}{cccccc}
\hline Algorithm & Outcome & Effect & Coefficient & AI Robust Standard errors & T-stat \\
\hline NNM & Firm Income & ATET & $36,660.17 * * *$ & 10886.39 & 3.37 \\
\hline Note. The asterisk & $* * *$ denote level of statistical significance at 1\%; AI Robust Standard errors are used to generate heteroskedastic-robust \\
variance estimators to correct for potential heterokedasticity (Abadie \& Imbens, 2002) Source: Own Computation from Study Data (2017).
\end{tabular}

Table 3 shows that the positive and statistically significant value for ATET was Kshs 36.660. This implies that, on average, the annual firm income increased by Kshs 36.660 when a firm participated in microfinance. The finding of this study is consistent with that of Crepon et al. (2015) who found that microcredit significantly increased firm income in Morocco where, on average, 65 percent of the firms from the sample had their average income increase by 40 percent as result of participation in microfinance. 
Tedeschi (2008) whose study was based in Peru, also found that microcredit increased microenterprise income for those micro entrepreneurs who chose to access microfinance loans. Their results were robust across both weekly and monthly enterprise income using a quasi-experimental technique as well as fixed effects. This study however, contradicts the studies by Tarozzi et al. (2015) in Ethiopia and Banerjee et al. (2015) in India who did not find any evidence of microfinance effects on entrepreneurial income except at the very top of the profit quintile. In addition, a study by Augsburg et al. (2015) in Bosnia and Herzegovina found mixed effects of MSE participation in microfinance on firm income.

The findings of the study propagate the view that microfinance services can help MSEs increase their entrepreneurial income. As these services are often in relatively small transactions, accessible and affordable, the MSEs can utilize them to meet their business liquidity needs, build technology stock, invest in productive assets, manage their working capital and expand their enterprises (Copestake et al., 2001; Tedeschi, 2008). Many of the MSEs can overcome the challenges they face such as inadequate capital, lack of access to affordable credit, lack of collateral and inadequate business skills (Republic of Kenya, 2013a).

To further assess the distributional effects of microfinance on MSE performance, the study considered aspects of gender of the owner, age of the firm and age group of the owner. The aspect of gender is justified on the premise that microfinance has been promoted as a tool for enhancing entrepreneurship especially among non-collaterized women (Yunus, 1999; Zeller, 1999). The variables of age of firm and age group of owner are motivated around the need to understand how government efforts to offer microfinance-type services to the youth enterprises may affect MSE performance (Republic of Kenya, 2011). The results of these effects are presented in the table that follows.

Table 4. Effects of MSE participation in microfinance for selected variables

\begin{tabular}{llcccc}
\hline Criteria & Class & ATET & AI Robust Errors & Prob value & N \\
\hline Gender of owner & Male & $24134.76^{*}$ & 12378.84 & 0.051 & 1404 \\
& Female & 12131.25 & 20596.15 & 0.556 & 417 \\
Age of firm & Quintile 1 (1 - 2 years) & $51,565.00^{* *}$ & 22208.65 & 0.020 & 613 \\
& Quintile 2 (3 - 4 years) & $32,432.04 *$ & 17402.79 & 0.062 & 382 \\
& Quintile 3 (5 - 9 years) & $33,420.51^{*}$ & 19713.44 & 0.090 & 405 \\
Age group of owner & Quintile 4 (> 10 years) & $24,221.54$ & 17761.98 & 0.173 & 427 \\
& Quintile 1 (16 - 26 years) & $-23,962.5$ & 30374.16 & 0.430 & 473 \\
& Quintile 2 (27 - 34 years) & $26,094.23$ & 24644.91 & 0.290 & 453 \\
& Quintile 3 (35 - 45 years) & $51509.09^{* *}$ & 23056.31 & 0.025 & 470 \\
& Quintile 4 (> 46 years) & $47251.09^{* *}$ & 21705.35 & 0.029 & 431 \\
\hline
\end{tabular}

Note. The asterisks ** and * denote level of statistical significance at $5 \%$ and $10 \%$ percent; AI Robust Standard errors are used to generate heteroskedastic-robust variance estimators to correct for potential heterokedasticity (Abadie \& Imbens, 2002). Source: Own Computation from Study Data (2017).

Table 4 reveals that on gender of firm owner, the value for ATET was 24,134 with ten percent level of significance on male firm owners only. This finding suggests that on average, microfinance had an effect on male-owned firms only. This scenario is interesting since microfinance is promoted to support female entrepreneurs more than male entrepreneurs. This result is consistent with that of Karlan and Zinman (2010) whose study in Philippines found out that microfinance had positive effects among male owned firms but not female owned firms. De Mel, McKenzie, and Woodruff (2009) also showed that the effects of micro enterprise participation in microfinance were higher among male owners than female owners in Sri Lanka. This means that there are possible gender gaps within society that may disadvantage women from achieving greater microfinance effects on their businesses. These gaps may be due to the patriarchal nature of the society in many developing countries hence less access to opportunities including financial access, education, training and less ownership of productive assets that may aid performance (De Mel, McKenzie, \& Woodruff, 2009; Wawire, 2010).

On age of the firm, the study established that microfinance had the greatest effects for firms whose ages were up to two years. For these firms, participation in microfinance, on average, increased their annual income by Kshs 51,565. This finding implies that the youngest firms derive the greatest effects from microfinance than the older firms (over 3 years). Therefore, supporting younger firms may be useful in sustaining and growing them, since they have the biggest risk of closing down. For instance, some of the reasons cited for closure or non-growth of MSEs in Kenya are lack of operating funds as well as low access to financial services (Berg et al., 2015; Republic of Kenya, 2016). 
The consideration of age group of owner was important in light of the Government of Kenya's efforts to support the youth entrepreneurship through programmes such as Youth Fund (Republic of Kenya, 2015). From the results, there was no evidence of microfinance effects on income of enterprises owned by individuals aged between 16 and 34 years. The lower bound age was considered in light of some firm owners starting their businesses after they drop out of school or decide to start their business before their majority age. For the age groups of 35 - 45 years and those over 46 years, the ATET was Kshs 51,509 and Kshs 47,251, respectively. This finding implies that the youth business owners (under 35 years) still suffer certain disadvantages such as low experience, training and risk taking abilities which may hinder them from realizing any impacts on their businesses through microfinance. However for the entrepreneurs aged between 35 and 45 years, microfinance effects are significant and greater than those firms whose owners are over 46 years old.

\section{Conclusions}

The study`s findings show that participation of MSEs in microfinance has a positive effect on their performance. It is therefore concluded that participation in microfinance is a catalyst for promoting MSE performance. However, since there was evidence that participation in microfinance did not have any effects on the income of female-owned firms, the study concludes that female-owned firms may be prone to gender-specific constraints that need to be addressed in order to increase their performance. This case applies also to firms owned by the youth $(<35$ years). On age of the firm, the study concludes that promoting participation in microfinance among firms whose ages are up to two years is important in promoting their performance since there were significant effects of microfinance on these firms.

Based on the findings of the study, a number of policy implications have been suggested. Foremost, the government and microfinance providers should put in place policies that would increase participation in microfinance by MSEs. This may be through government and microfinance providers encouraging and upscaling financial literacy programmes and also creating incentives that would increase acquisition of permits and licences by MSEs. To increase performance of youth-owned MSEs (owners who are below 35 years), the government and microfinance providers should address youth-specific barriers that prevent these MSEs from deriving any effects of participation in microfinance. These barriers may include lack of business training and little business experience. This implication rests on the finding that participation in microfinance did not , on average, have any effects for firms whose owners were below 35 years.

In view of supporting young businesses, the government should provide incentives that promote participation in microfinance by MSEs especially those that are below two years of age. This is because the findings indicated that participation in microfinance had the greatest effects among firms in this age bracket. Possible incentives include business training and support, opening up new markets and promoting competitiveness of the MSEs. In addition, microfinance providers should tailor-make their products that provide adequate operating funds and business support to these businesses. Such incentives and products may assist a large number of firms who close their businesses in their early years of operation due to lack of access to operating funds.

In light of the finding that only male-owned firms derived positive and significant impacts from participating in microfinance, the government and microfinance providers should address obstacles that hinder women-owned firms from benefitting from participation in microfinance. Commonly cited obstacles include; less access to financing opportunities, less ownership of productive assets and inadequate business training. Therefore existing programmes and products such as the Women Fund should be upscaled to overcome some of these challenges. Also, products that de-emphasize collateral and promote women training in business should be encouraged. However, a full understanding of the interaction between women specific constraints and participation in microfinance requires a further study.

\section{References}

Abadie, A., \& Imbens, G. (2002). Simple and Bias-Corrected Matching Estimators. Technical report, Department of Economics, University of California, Berkeley. https://doi.org/10.3386/t0283

Armendariz, B., \& Morduch, J. (2005). Beyond Group Lending. Economics of Transition, 8(2), 401-420. https://doi.org/10.1111/1468-0351.00049

Augsburg, B., De Haas, R., Harmgart, H., \& Meghir, C. (2015). Impacts of Microcredit: Evidence from Bosnia and Herzegovina. American Economic Journal: Applied Economics, 7, 183-203. https://doi.org/10.1257/app.20130272

Awotide, B., Abdoulaye, T., Alene, A., \& Manyong,V. (2015). Impact of Access to Credit on Agricultural Productivity: Evidence from Smallholder Cassava Farmers in Nigeria. Prepared for Oral Presentation at the 
International Conference of Agricultural Economists (ICAE) Milan, Italy August 9-14, 2015.

Banerjee, A., Duflo, E., Glennerster, R., \& Kinnan, C. (2015). The Miracle of Microfinance? Evidence from a Randomized Evaluation. American Economic Journal of Applied Economics, 7, 22-53. https://doi.org/10.1257/app.20130533

Central Bank of Kenya, Kenya National Bureau of Statistics \& FSD Kenya. (2016). Presentation of the 2016 FinAccess Household Survey on financial inclusion. Nairobi, Kenya: FSD Kenya.

Central Bank of Kenya. (2015). Bank Supervision Annual Report. Nairobi: Central Bank of Kenya.

Coase, R. H. (1937). The Nature of the Firm. Economica, 4, 386-405.

Copestake, J., Bhalortra, S., \& Johnson, S. (2001). Assessing the Impact of Microcredit: A Zambia Case Study. Journal of Development Studies, 37(4), 81-100. https://doi.org/10.1080/00220380412331322051

Copestake, J., Dawson, P., Fanning, J. P., McKay, A., \&Wright-Revolledo, K. (2005). Monitoring the Diversity of the Poverty Outreach and Impact of Microfinance: A Comparison of Methods Using Data from Peru. Development Policy Review, 23(6), 703-723. https://doi.org/10.1111/j.1467-7679.2005.00309.x

Crepon, B., Devoto, F., Duflo, E., \& Parient, W. (2015). Estimating the Impact of Microcredit on Those Who Take It Up: Evidence from a Randomized Experiment in Morocco. American Economic Journal of Applied Economics, 7, 123-50. https://doi.org/10.1257/app.20130535

De Mel, S., Mckenzie, D., \& Woodruff, C. (2008). Returns to Capital in Microenterprises: Evidence from a Field $\begin{array}{lllll}\text { Experiment. The Quarterly Journal of Economics, 123, 1329-1372. } & \text {. }\end{array}$ https://doi.org/10.1162/qjec.2008.123.4.1329

De Mel, S., McKenzie, D., \& Woodruff, C. (2009). Are Women More Credit Constrained? Experimental Evidence on Gender and Microenterprise Returns. American Economic Journal: Applied Economics, 1-32. https://doi.org/10.1257/app.1.3.1

Demirguc-Kunt, A., \& Klapper, L. (2012). Measuring Financial Inclusion, The Global Findex Database. World Bank Policy Research Working Paper, 6025. https://doi.org/10.1596/1813-9450-6025

Karlan, D., \& Zinman, J. (2010). Expanding Credit Access: Using Randomized Supply Decisions to Estimate the Impacts. Review of Financial Studies, 23(1), 433-464. https://doi.org/10.1093/rfs/hhp092

Knight, F. H. (1921). Risk, Uncertainty, and Profit. New York: Harper and Row.

Miller, M., Godfrey, N., Levesque, B., \& Stark, E. (2009). The Case for Financial Literacy in Developing Countries: Promoting Access to Finance by Empowering Consumers. World Bank, DFID, OECD, and CGAP Joint note, Washington, DC: World Bank.

Republic of Kenya. (1986). Sessional Paper No. 1 of 1986 on Economic Management for Renewed Growth. Nairobi: Government Printer.

Republic of Kenya. (1992). Sessional Paper No 2 of 1992 on Small Enterprises and Jua Kali Development in Kenya. Nairobi: Government Printer.

Republic of Kenya. (1999). National Micro and Small Enterprise Baseline Survey. Nairobi: Central Bureau of Statistics.

Republic of Kenya. (2005). Sessional Paper Number 2 of 2005 on the Development of Micro and Small Scale Enterprises for Wealth and Employment Creation for Poverty Reduction. Nairobi: Government Printer.

Republic of Kenya. (2007). Kenya Vision 2030: A Globally Competitive and Prosperous Kenya. Nairobi: Government Printer.

Republic of Kenya. (2011). Youth Enterprise Development Fund Status Report. Nairobi: Government Printer.

Republic of Kenya. (2012). Micro and Small Enterprises Act. Nairobi: Government Printer.

Republic of Kenya. (2013a). Second Medium Term Plan, 2013-2017. Nairobi: Government Printer.

Republic of Kenya. (2013b). Kenya Industrial Estates Strategic Plan (2013-2017). Nairobi: Government Printer.

Republic of Kenya. (2015). Kenya Economic Survey. Nairobi: Government Printer.

Republic of Kenya. (2016). Micro, Small and Medium Establishments: Basic Report. Nairobi: Kenya National Bureau of Statistics

Rooyen, C. V., Stewart, R., \& Wet, T. E. (2012). The Impact of Microfinance Sub-Saharan Africa: A Systematic 
Review of the Evidence. World Development, 40(11), 2249-2262. https://doi.org/10.1016/j.worlddev.2012.03.012

Rosenbaum, P. R., \& Rubin, D. B. (1983). The Central Role of the Propensity Score in Observational Studies for Causal Effects. Biometrica, 70(1), 41-55. https://doi.org/10.1093/biomet/70.1.41

Smith, A. (1776). An Enquiry into the Wealth of Nations. Oxford: Clarendon Press.

Smith, J. A., \& Todd, P. E. (2005). Does Matching Overcome Lalonde's Critique of Non experimental Estimators? Journal of Econometrics, 125, 305-35.

Tarozzi, A., Desai, J., \& Johnson, K. (2015) Impacts of Microcredit: Evidence from Ethiopia. American Economic Journal: Applied Economics, 7, 54-89. https://doi.org/10.1257/app.20130475

Tedeschi, G. A. (2008). Overcoming Selection Bias in Microcredit Impact Assessments: A Case Study in Peru. Journal of Development Studies, 44, 504-518. https://doi.org/10.1080/00220380801980822

Verbeek, M. (2012). A Guide to Modern Econometrics (4th ed.). West Sussex: John Wiley and Sons.

Wawire, N. H. W., \& Nafukho, F. M. (2010). Factors Affecting the Management of Women Groups' Micro and Small Enterprises in Kakamega District, Kenya. Journal of European Industrial Training, 34(2), 128-152. https://doi.org/10.1108/03090591011023989

World Bank. (2016). Doing Business in Kenya. Washington DC: World Bank. https://doi.org/10.1596/978-1-4648-0948-4

Yunus, M. (1999). Banker to the Poor: Micro-lending and the Battle against World Poverty. New York: Public Affairs.

Zeller, M. (1999). The Role of Micro-Finance for Income and Consumption Smoothing. Paper presented at the Inter-American Development Bank Conference on Social Protection and Poverty on February 5, 1999, Organized by the Poverty and Inequality Advisory Unit of the Sustainable Development Department Washington D.C.

\section{Appendix}

Table A1. Output of the probit regression of determinants of MSE participation in microfinance

\begin{tabular}{|c|c|c|c|c|}
\hline \multirow{2}{*}{$\begin{array}{l}\text { Dependent variable (dummy variable) } \\
\text { Independent Variables }\end{array}$} & \multicolumn{4}{|c|}{ Dependent variable $=1$ if an MSE participated in microfinance and 0 otherwise } \\
\hline & Coefficient & Robust Std Errors & Z Value & P Value \\
\hline Number of business units in a firm & 0.1319725 & 0.0669067 & 1.97 & 0.049 \\
\hline Age & 0.0914926 & 0.0136269 & 6.71 & 0.000 \\
\hline Age squared & -0.0008756 & 0.0001531 & -5.72 & 0.000 \\
\hline Education (No Education) & -0.5709062 & 0.2039943 & -2.8 & 0.005 \\
\hline Education (Primary) & -0.0262856 & 0.1144666 & -0.23 & 0.818 \\
\hline Education (Secondary) & 0.1156876 & 0.1114983 & 1.04 & 0.299 \\
\hline Gender & 0.0945059 & 0.0820885 & 1.15 & 0.250 \\
\hline Financially literacy level (Literate) & 0.4641441 & 0.1008391 & 4.6 & 0.000 \\
\hline Numeracy level (Numerate) & -0.151356 & 0.0821514 & -1.84 & 0.065 \\
\hline Ownership of radio (Yes) & 0.1620364 & 0.0740175 & 2.19 & 0.029 \\
\hline Age of firm & 0.0091025 & 0.0042798 & 2.13 & 0.033 \\
\hline Number of employees & 0.0394649 & 0.0205755 & 1.92 & 0.055 \\
\hline Location type of firm (Fixed) & 0.091994 & 0.0793153 & 1.16 & 0.246 \\
\hline Permit (Yes) & 0.2956008 & 0.0919879 & 3.21 & 0.001 \\
\hline Registration of firm (Yes) & -0.028289 & 0.1224297 & -0.23 & 0.817 \\
\hline Ownership of motorcycle (Yes) & -0.0228459 & 0.0957172 & -0.24 & 0.811 \\
\hline Ownership of bicycle (Yes) & 0.0899654 & 0.0826147 & 1.09 & 0.276 \\
\hline Credit Policy - Inward (Yes) & 0.0797129 & 0.0814326 & 0.98 & 0.328 \\
\hline Credit Policy - Outward (Yes) & 0.0700334 & 0.074838 & 0.94 & 0.349 \\
\hline Bank finance participation (Yes) & 0.5435744 & 0.1319776 & 4.12 & 0.000 \\
\hline
\end{tabular}

Note . Number of Observations $=1821 ;$ Wald Ci square $(20)=227.83 ;$ Prob > chi2 $=0.0000$; Tertiary education is the reference level. Source: Own Computation from Study Data (2017). 
Table A2. Results of the multicollinearity test, goodness of fit and heteroscedasticity for probit model of determinants of MSE participation in microfinance

\begin{tabular}{ll}
\hline Link test for Model Specification of the Probit Model & \\
\hline Microfinance Participation & Coefficient (Probability) \\
hat & $0.9858888(0.000)$ \\
hatsq & $-0.010769(0.901)$ \\
Constant & $-0.0017877(0.973)$ \\
\hline Goodness of Fit using Hosmer-Lemeshow Test & $1821(10)$ \\
\hline Number of observations (groups) & 5.17 \\
Hosmer-Lemeshow Chi2(8) & 0.7398 \\
Prob > Chi2 & \\
\hline Heterokedasticity using Langrange Multiplier test & 26.37 \\
\hline LM statistic & 0.1201 \\
\hline Prob > Chi2 (19) & \\
\hline
\end{tabular}

Source: Own Computation from Study Data (2017).

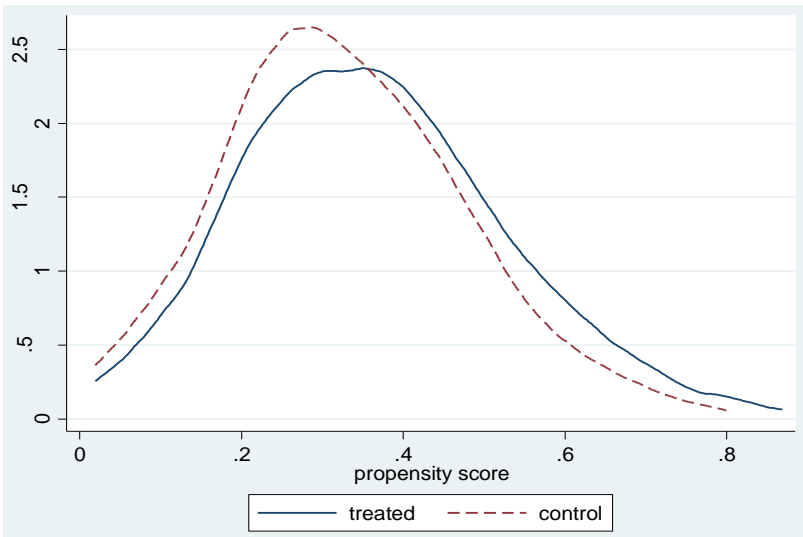

Figure A1. Density distribution of the propensity score for the treated and control variable after matching

Table A3. Balancing test of matched sample for effects of MSE participation in microfinance on MSE performance

\begin{tabular}{lccc}
\hline Independent Variables & \multicolumn{2}{c}{ Mean values } & Prob \\
\cline { 2 - 3 } & Participants & Non-participants & 0.541 \\
Number of business units & 1.1426 & 1.1191 & 0.228 \\
Age & 40.179 & 41.189 & 0.260 \\
Age squared & 1777.2 & 1862.7 & 0.826 \\
Education (No Education) & 0.0212 & 0.0234 & 1.000 \\
Education (Primary) & 0.40213 & 0.40213 & 0.554 \\
Education (Secondary) & 0.4234 & 0.44255 & 0.351 \\
Education (Tertiary) & 0.15319 & 0.13191 & 0.624 \\
Gender & 0.79574 & 0.80851 & 0.522 \\
Financially literacy level (Literate) & 0.90213 & 0.88936 & 0.689 \\
Numeracy level (Numerate) & 0.20426 & 0.21489 & 0.120 \\
Ownership of radio (Yes) & 0.71915 & 0.72979 & 0.243 \\
Age of Business & 7.6702 & 8.4298 & 0.238 \\
Employees & 1.9149 & 1.7617 & 0.839 \\
Location type of business (Fixed) & 0.75106 & 0.71702 & 1.000 \\
Permit (Yes) & 0.3617 & 0.35532 & 0.474 \\
Registration of business (Yes) & 0.14468 & 0.14468 & 0.881 \\
Ownership of motorcycle (Yes) & 0.16596 & 0.14894 & 0.464 \\
Ownership of bicycle (Yes) & 0.25745 & 0.25319 & 0.693 \\
Credit Policy - Inward (Yes) & 0.7383 & 0.71702 & 0.614 \\
Credit Policy - Outward (Yes) & 0.44043 & 0.42766 & 0.11277 \\
Bank finance participation (Yes) & 0.1234 & & \\
\hline
\end{tabular}

Source: Own Computation from Study Data (2017).

\section{Copyrights}

Copyright for this article is retained by the author(s), with first publication rights granted to the journal.

This is an open-access article distributed under the terms and conditions of the Creative Commons Attribution license (http://creativecommons.org/licenses/by/4.0/). 